\title{
An Empirical Study on the Influencing Factors of Consumers' Fresh Agricultural Products Purchase Behavior
}

\author{
Qianqian Zhuang \\ School of Management and Economics Beijing Institute of Technology, Beijing, China \\ Email:1120152951@Bit.edu.cn \\ *Corresponding: Qianqian Zhuang Tel: 18811378328
}

Keywords: consumer online shopping; fresh agricultural products; demand and behavior; survey

\begin{abstract}
Under the background of "Internet plus", e-commerce has provided a good platform for the sale of fresh agricultural products on the Internet. Although e-commerce of fresh agricultural products has made great progress, there are still many problems. Through the literature review, this paper puts forward the research issues of this paper. Aiming at these problems, a questionnaire survey was conducted on perceived benefits, consumption experience, online shopping risks and online commodity information quality. Through a large sample of questionnaires and structural equation model analysis, the results show that perceived benefits, consumption experience, online commodity information quality can directly affect consumers' purchase behavior for fresh agricultural products, and online shopping risk inhibits consumers' purchase behavior too. Based on the empirical results of this paper, the development countermeasures of e-commerce for fresh agricultural products are put forward from three aspects: consumers' demand for fresh agricultural products online, the social recognition of fresh agricultural products online, and the optimization of commodity supply structure of fresh agricultural products platform.
\end{abstract}

\section{Introduction}

In people's daily life, farmers 'markets and supermarkets are the traditional channels to purchase fresh agricultural products. With the development of society and the quickening pace of urban life, it is difficult for nine to five workers to have time to go to farmers' markets and supermarkets for purchasing. Fresh agricultural products are rotten and discarded due to unsalable, which seriously affects the healthy development of the fresh agricultural products market in China. Against the plight of traditional channel sales, e-commerce has provided a good platform for the sale of fresh agricultural products on the Internet under the background of "Internet plus". Fresh products for the field of e-commerce can be thought of as a "blue sea", and in the context of e-commerce industry to obtain high sales volumes, major enterprises have also based on their own resource advantages to test fresh e-commerce market. From Jingdong Shopping Mall with its platform advantages to make businesses settle in the fresh channel, then to Shunfeng Preferred, Original Living Network, Youcai Network, Amazon China, No. 1 Shop and other fresh product e-commerce online operation, the domestic fresh product e-commerce enterprises show a trend of explosive growth in a short period of time. These e-commerce platforms display real-time prices of agricultural products online, and coordinate the supply of products internally, so that fresh agricultural products gradually step out of the "high purchasing, hard to sell" dilemma. Although the e-commerce of fresh agricultural products has made great progress, there are still many problems.

At present, domestic and foreign scholars on fresh e-commerce research mainly includes: cold chain logistics research, Fan Junhua (2018) proposed "farmer-supermarket docking" short chain circulation model, and Yin Shi-long (2016) thought that cold chain infrastructure is poor, and logistics distribution system is imperfect; network trust mechanism research, Lin Jiabao et al. (2015) thought it difficult to establish a long-term mechanism for those easily perishable, high timely and strongly experiencingfresh agricultural products; supplier evaluation research, Wang Yong (2018) proposed supplier system evaluation based on the construction of supplier evaluation model index 
system; fresh agricultural products online shopping satisfaction factors research, Wu Weiqun (2017) proposed fresh agricultural products online reputation,online shopping platform, perceived value and perceived quality have significant positive effects on consumers'satisfaction with fresh agricultural products. In view of the current research status, based on the survey of consumers'demand for fresh agricultural products on-linecombining questionnaire, this paper makes an empirical analysis of perceived benefits, consumption experience, online shopping risks, online commodity information quality and consumers' purchase behavior of fresh agricultural products, with a view to put forward more targeted suggestions for further developing fresh agricultural products e-commerce.

\section{Research hypotheses}

In the technology acceptance model studied by Jarvenpaa \& Todd (1997), Lei-da Chen, Justin Tan (2004), Hung-Pin Shih (2004) et al., only when online consumers believe that online shopping can provide rich, timely and accurate information about fresh agricultural products and services, and consumers can save time and energy, save costs, so consumers can produce purchasing behavior. Accordingly, the following assumptions are made:

H1: Convenient and useful online shopping is positively correlated with the purchase behavior of consumers' fresh agricultural products;

Zeithaml (2008) holds that the important factor that influences consumers' purchase intention is their online shopping experience, especially the positive customer feedback from experiential service to fresh agricultural products. Hausman and Siekpe (2009), through empirical research on some online shopping, point out that pleasant online shopping experience can affect customers' purchase behavior, and particularly, knowledge of relevant products is more likely to affect consumers' purchase intention. Accordingly, the research hypothesis is put forward.

H2: Consumption experience is positively correlated with the purchase behavior of consumers' fresh agricultural products;

Cass and Fenech et al. (2013) pointed out that online consumption of fresh agricultural products, because its process is completed in a virtual space transaction, lack of access to fresh agricultural products in advance, will make consumers uncomfortable. By empirical studies of online retailing behavior, Koufarisand Hampton-Sosa and Sultan et al.have demonstrated that privacy is negatively correlated with security control, product delivery lag, counterfeit and inferior products, product refund and consumer trust. Accordingly, the research hypothesis is put forward.

H3: Online shopping risk is negatively correlated with the purchase behavior of consumers' fresh agricultural products;

Through empirical study with online and offline two types of consumer purchase behavior of fresh agricultural products, and regression analysis, Sullivan and Walstrom (2001) respectively concluded that information quality has a significant impact on consumer purchase behavior of fresh agricultural products. Accordingly, the research hypothesis is put forward.

H4: information quality is positively correlated with the purchase behavior of consumers' fresh agricultural products.

\section{Research design}

\subsection{Data sources}

This article mainly chooses consumers who have purchased fresh agricultural products on Taobao, eBay, Dangdang, Jingdong online shopping mall, Pat and other websites. The survey was divided into two stages, the first (January-April 2018) and the second (May-July 2018). In the first survey, the author interviewed some friends who often bought fresh agricultural products online and had rich experience in purchasing fresh agricultural products online, and conducted a trial survey. At the same time, according to the results of the survey, the questionnaire was revised and improved. Finally, the Level 7 Likert Scale was used. In the second normal survey, 570 questionnaires were 
sent out. Most of the respondents lived in Beijing, Nanjing, Shanghai and Suzhou. After manual examination, all the questionnaires with the same answer or missing key variable data were deleted, including 78 invalid questionnaires. There were 492 valid questionnaires, with an effective rate of $82.7 \%$.

\subsection{Selection of variables}

Based on market research and literature review, this paper divides the factors of affecting online consumers' purchasing intention into perceived benefits, consumption experience, online shopping risk, information quality and other dimensions, and selects variables as shown in Table 1.

Table 1 research dimensions and specific indicators

\begin{tabular}{|c|c|c|}
\hline Dimension & Specific indicator & Number \\
\hline \multirow{4}{*}{$\begin{array}{l}\text { Perceived } \\
\text { benefits } \\
\text { online } \\
\text { shopping }\end{array}$} & $\begin{array}{l}\text { Easy to find the needed commodity information in fresh agricultural } \\
\text { products website. }\end{array}$ & A1 \\
\hline & $\begin{array}{l}\text { The products delivered by the fresh agricultural products website } \\
\text { are consistent with the actual purchase. }\end{array}$ & A2 \\
\hline & Fresh agricultural products website provides quick delivery mode. & A3 \\
\hline & $\begin{array}{l}\text { The package of fresh agricultural products website served to me is } \\
\text { intact and intact. }\end{array}$ & A4 \\
\hline \multirow{3}{*}{$\begin{array}{l}\text { Consumption } \\
\text { experience }\end{array}$} & $\begin{array}{l}\text { Knowledge of products can make reasonable purchase decisions for } \\
\text { online shopping. }\end{array}$ & B1 \\
\hline & $\begin{array}{l}\text { Fresh agricultural products website staff can reply to my queries in } \\
\text { time. }\end{array}$ & B2 \\
\hline & $\begin{array}{l}\text { Familiar friends, pleasant shopping experience, and the impact of } \\
\text { shopping. }\end{array}$ & B3 \\
\hline \multirow{4}{*}{$\begin{array}{l}\text { Online } \\
\text { shopping risk }\end{array}$} & Accounts and passwords may be embezzled. & C1 \\
\hline & Product delivery lag risk & $\mathrm{C} 2$ \\
\hline & Fake and shoddy products & C3 \\
\hline & Product replacement and maintenance risks & C4 \\
\hline \multirow{3}{*}{$\begin{array}{l}\text { Information } \\
\text { quality }\end{array}$} & $\begin{array}{l}\text { The product information (production date, place of origin) provided } \\
\text { by the website is reliable. }\end{array}$ & D1 \\
\hline & $\begin{array}{l}\text { The pictures of fresh products provided by the website are in line } \\
\text { with the actual picture. }\end{array}$ & D2 \\
\hline & $\begin{array}{l}\text { The relevant information of the website's fresh produce can be } \\
\text { updated and replenish in time. }\end{array}$ & D3 \\
\hline $\begin{array}{l}\text { Consumers' } \\
\text { purchase } \\
\text { behavior }\end{array}$ & Purchase of fresh agricultural commodities & E1 \\
\hline
\end{tabular}

\section{Empirical results analysis}

\subsection{Will consumers choose to purchase fresh agricultural products online?}

The data collected from 492 valid questionnaires show that 191 consumers have experienced online purchasing fresh agricultural products, accounting for $38.82 \%$ of the total, and 301 consumers have not experienced online purchasing fresh agricultural products, accounting for $61.18 \%$ of the total. The survey results show that most of the consumers have no experience in purchasing fresh agricultural products online, and the behavior of purchasing fresh agricultural products online has not been popular among consumers. Chi-square test can be used to determine whether individual differences of consumers have an impact on online purchasing of fresh agricultural products. SPSS19.0 was used to test the sex, age, educational background, occupation, monthly income, living place, family size and the behavior of those consumers purchasing fresh agricultural products online. The results were shown in Table 2. 
Table 2 Chi square test results

\begin{tabular}{c|c|c|c|c|c|c|c}
\hline & Sex & age & education & occupation & $\begin{array}{c}\text { monthly } \\
\text { income }\end{array}$ & Living place & $\begin{array}{c}\text { Family } \\
\text { size }\end{array}$ \\
\hline $\begin{array}{c}\text { Bilateral } \\
\text { test value }\end{array}$ & 0.188 & 0.071 & 0.910 & 0.124 & 0.012 & 0.176 & 0.541 \\
\hline
\end{tabular}

Comparing the results in Table 2 with the significant level of 0.05 , it can be seen that only 0.012 is less than 0.05 , that is to say, among the individual characteristics of consumers, only monthly income affects whether consumers will purchase fresh agricultural products online or not, and other individual characteristics basically have no effect on consumers' behavior to purchase fresh agricultural products online.

Through the data analysis of the questionnaire, the monthly income of consumers can be compared with whether there is online purchase of fresh agricultural products, as shown in Table 3.

Table 3 statisticdata for different monthly income consumerson online shopping fresh agricultural products

\begin{tabular}{c|c|c}
\hline $\begin{array}{c}\text { Monthly income of consumers } \\
\text { (yuan) }\end{array}$ & $\begin{array}{c}\text { Online purchase of fresh } \\
\text { agricultural products (\%) }\end{array}$ & $\begin{array}{c}\text { No online purchase of fresh } \\
\text { agricultural products (\%) }\end{array}$ \\
\hline Less than 1500 yuan & 13.81 & 86.19 \\
\hline $1500-2500$ yuan & 12.05 & 87.95 \\
\hline $2500-3500$ yuan & 17.18 & 82.82 \\
\hline $3500-4500$ yuan & 18.13 & 81.87 \\
\hline 4500-10000 yuan & 32.69 & 67.31 \\
\hline More than 10000 yuan & 48.24 & 51.76 \\
\hline
\end{tabular}

From table 3, we can see that the proportion of consumers with monthly income of less than 4500 Yuan who have purchased fresh agricultural products is similar, but the proportion of consumers with monthly income of more than 4500 yuan who have purchased fresh agricultural products is significantly higher than that of consumers with monthly income of less than 4500 yuan. The higher the income is, the greater the proportion of online shopping fresh agricultural products is. Of the consumers who earn more than 10000 yuan a month, $48.24 \%$ have bought fresh produce online. So, high income groups choose a relatively large proportion of online shopping fresh agricultural products.

\subsection{Reliability and validity of the questionnaire}

Table 4 reliability and validity of variables

\begin{tabular}{|c|c|c|c|c|c|c|c|}
\hline \multirow[b]{2}{*}{ Latent variable } & \multirow{2}{*}{$\begin{array}{l}\text { Variable } \\
\text { metric }\end{array}$} & \multicolumn{2}{|c|}{ Descriptive statistics } & \multirow{2}{*}{$\begin{array}{l}\text { Factor } \\
\text { reduction } \\
\text { coefficient }\end{array}$} & \multirow{2}{*}{$\begin{array}{c}\text { Contribution } \\
\text { rate of } \\
\text { principal } \\
\text { component } \\
\text { variance (\%) }\end{array}$} & \multirow[b]{2}{*}{$\begin{array}{c}\text { Cronbach's } \\
\text { a }\end{array}$} & \multirow[b]{2}{*}{ AVE } \\
\hline & & $\begin{array}{l}\text { Mean } \\
\text { value }\end{array}$ & $\begin{array}{l}\text { Standard } \\
\text { deviation }\end{array}$ & & & & \\
\hline \multirow{4}{*}{$\begin{array}{l}\text { Perceived } \\
\text { benefits of } \\
\text { online } \\
\text { shopping }\end{array}$} & A1 & 4.17 & 1.24 & 0.763 & \multirow{4}{*}{67.72} & \multirow{4}{*}{0.826} & \multirow{4}{*}{1.613} \\
\hline & A2 & 4.52 & 1.13 & 0.752 & & & \\
\hline & A3 & 4.65 & 1.28 & 0.733 & & & \\
\hline & A4 & 4.33 & 1.17 & 0.832 & & & \\
\hline \multirow{3}{*}{$\begin{array}{l}\text { Consumption } \\
\text { experience }\end{array}$} & B1 & 5.16 & 0.98 & 0.824 & \multirow{3}{*}{75.83} & \multirow{3}{*}{0.738} & \multirow{3}{*}{1.415} \\
\hline & $\mathrm{B} 2$ & 5.44 & 1.44 & 0.815 & & & \\
\hline & B3 & 4.98 & 1.34 & 0.803 & & & \\
\hline \multirow{4}{*}{$\begin{array}{c}\text { Online } \\
\text { shopping risk }\end{array}$} & C1 & 5.36 & 1.36 & 0.812 & \multirow{4}{*}{79.12} & \multirow{4}{*}{0.846} & \multirow{4}{*}{1.473} \\
\hline & $\mathrm{C} 2$ & 5.48 & 1.48 & 0.833 & & & \\
\hline & $\mathrm{C} 3$ & 5.31 & 1.32 & 0.806 & & & \\
\hline & C4 & 5.23 & 1.19 & 0.812 & & & \\
\hline \multirow{3}{*}{$\begin{array}{c}\text { Information } \\
\text { quality }\end{array}$} & D1 & 4.94 & 1.24 & 0.714 & \multirow{3}{*}{73.58} & \multirow{3}{*}{0.783} & \multirow{3}{*}{1.605} \\
\hline & D2 & 5.08 & 1.31 & 0.722 & & & \\
\hline & D3 & 5.34 & 1.26 & 0.715 & & & \\
\hline
\end{tabular}


In order to ensure the scientificity of model hypothesis validation, we must analyze the questionnaire data and test the reliability and validity of the sample data to ensure its effectiveness. In this study, the KMO value is greater than 0.7 and the Bartlett statistic value is significantly different from that of 0 . In the process of validity test using principal component analysis, Cronbach's a value is greater than 0.35 according to the characteristic root is greater than 1 and the maximum factor load is greater than 0.5 . The Cronbach's a value is not significantly improved after deleting any item, indicating that it has better content validity. Table 4 shows that Cronbach's values meet the requirements of not less than 0.70 . The reliability of the samples is tested by internal consistency test, and the variables have high internal consistency. Structural equation model analysis can be carried out.

\subsection{Overall SEM model checking and path coefficient determination}

AMOS 7.0 software is used to test the sample data. In this paper, $\chi 2 / \mathrm{d} \mathrm{f} 、 \mathrm{P} 、$ AGFI、IFI、CFI、 NFI、TLI、RMSEA and other indicators with good stability are selected to evaluate the fitting of the whole model. Using AMOS software to analyze and calculate the initial structural equation model, after importing the data, we can get the various indicators estimated by SEM model. But some indicators are not within the acceptable range of fitting, and need to be improved. According to the revised index and principle of Houtaijie et al. (2004), the imported data were fitted again with AMOS 7.0, and the initial model was adjusted and revised. As shown in Table 6, the absolute fitting index $\chi 2 /$ d.f $=2.751, \mathrm{P}=0.035$, AGFI $=0.970$, GFI $=0.912$ are all better than the recommended values; the relative fitting index IFI $=0.923, \mathrm{CFI}=0.967, \mathrm{~N}=0.035 \mathrm{FI}=0.923$ and $\mathrm{TLI}=0.968$ are better than the recommended values; the residual analysis RMSEA $=0.062$ is less than 0.08 of the upper limit. It can be seen that the fitting value has reached an acceptable range and the fitting degree between the model and the data is good. The model is considered to pass the fitting degree test.

After the model has passed the fitness test, the path coefficient needs to be further measured to evaluate the interpretation ability of the equation to the data and the verification of the hypothesis. Through the analysis of AMOS 7.0 software, the path coefficients of perceived benefits, consumption experience, online shopping risk and information quality on consumers' fresh agricultural products purchasing behavior are obtained. The load of the measurement model and the corresponding CR value are listed in Table 5. In this study, it can be seen that Ypt1 (coefficient of path Ypt $1=0.382, \mathrm{P}=0.002<0.05$ ), Ypt2 (coefficient of path Ypt2 $=0.344, \mathrm{P}=0.000<0.001$ ), Ypt3 (coefficient of path Ypt3 $=-0.341, \mathrm{P}=0.009<0.05$ ), Ypt4 (coefficient of path Ypt4 = 0.319, $\mathrm{P}$ $=0.002<0.05)$, the corresponding CR values of pathsused in the structural equation model are all higher than the reference value 1.96, indicating that the load coefficients at the $\mathrm{P}=0.05$ level are statistically significant. H1, H2, H3 and H4 are tested by hypothesis test.

Table 5 path coefficient and test of influencing factors on purchasing behaviour of consumer fresh agricultural products

\begin{tabular}{c|c|c|c|c|c|c}
\hline Path & Hypothesis & $\begin{array}{l}\text { Path } \\
\text { standardized } \\
\text { estimation } \\
\text { value }\end{array}$ & CR & P & $\begin{array}{c}\text { Correspondence } \\
\text { hypothesis }\end{array}$ & results \\
\hline Ypt1 & $\begin{array}{c}\text { Online shopping is convenient and } \\
\text { useful<--- purchasing behavior }\end{array}$ & 0.382 & 2.314 & 0.002 & H1 & adopted \\
\hline Ypt2 & $\begin{array}{c}\text { Consumption experience }<--- \\
\text { purchasing behavior }\end{array}$ & 0.344 & 3.697 & 0.000 & H2 & adopted \\
\hline Ypt3 & $\begin{array}{c}\text { Online shopping risk <--- } \\
\text { purchasing behavior }\end{array}$ & -0.341 & 3.782 & 0.009 & H3 & adopted \\
\hline Ypt4 & $\begin{array}{c}\text { Information quality <--- purchasing } \\
\text { behavior }\end{array}$ & 0.314 & 6.342 & 0.002 & H4 & adopted \\
\hline
\end{tabular}

The results of structural equation model on the convenience and usefulness of online shopping affecting consumers 'purchase behavior of fresh agricultural products show: H1 (the coefficient of 
path Ypt1 $=0.382, \mathrm{P}=0.002<0.05$ ) is validated. "Easy to find the information about the goods needed on this website", "the goods delivered on this website are consistent with the actual purchase", "Providing a quick delivery method, the goods delivered on this website are well packaged and undamaged", and so on, will promote consumers' fresh agricultural products purchase behavior.

The results of structural equation model on the influence of consumption experience with the purchase behavior of fresh agricultural products show: (the coefficient of path Ypt2 $=0.344, \mathrm{P}=$ $0.000<0.001$ ) is verified. "Product knowledge can make a reasonable purchase decision for online shopping", "website staff can respond to my relevant questions in a timely manner", "familiar friends happy shopping experience has a shopping impact" and so on will enhance consumer fresh agricultural products purchase behavior.

The results of Structural Equation Model for consumers' to purchase fresh agricultural products show: H3 (coefficient of path Ypt3 $=-0.341, \mathrm{P}=0.009<0.05$ ), lag of product distribution, fake and inferior products, possible misappropriation of account password and difficulty of product refund all affect consumers' purchasing and inhibit consumers' purchasing behavior of fresh agricultural products.

The results of structural equation model show: H4 (the coefficient of path Ypt4 $=0.319, \mathrm{P}=$ $0.002<0.05$ ) had an effect on consumers' purchasing behavior of fresh agricultural products. "The commodity information provided by this website (date of production, origin, etc.) is true and reliable", "the pictures of fresh commodities provided by this website conform to the reality", "the relevant information of fresh commodities on this website can be updated and supplemented in time" and so on will promote consumers’ purchase behavior of fresh agricultural products.

\section{Conclusions}

Through the analysis of the questionnaire data, this paper verifies that the convenience of online shopping, consumer experience and online information quality have a significant positive impact on consumers' purchasing behavior of fresh agricultural products. The risk of online shopping is negatively related to consumers' purchase behavior of fresh agricultural products. The risk of online shopping resists the purchase of online consumers. Based on this, the following suggestions are put forward:

\subsection{Consumer demand for fresh produce online shopping}

The vast majority of consumers hope that their online purchase price of fresh agricultural products is lower than $15 \%$ of the farmer's market on the basis of quality assurance, and most consumers hope that a single online purchase of fresh agricultural products is between 50-100 yuan. From the viewpoint of payment, most consumers like to pay with Alipay and WeChat, and most consumers like to use mobile terminals to purchase fresh agricultural products online. Most consumers hope that when they purchase fresh agricultural products online, the manufacturer can guarantee the quality of the products, and the manufacturer can provide product traceability service. In terms of logistics, most consumers want the E-commerce platform to deliver fresh agricultural products faster when they purchase them online, and hope that the products in the logistics process are less damaged or basically not.

\subsection{Social recognition of online fresh agricultural products}

The monthly income of consumers affects whether consumers will have the behavior of purchasing fresh produce online. The higher the monthly income 十, the greater the degree of recognition of online shopping is. Most consumers do not purchase fresh agricultural products online because they are worried about the freshness. Most consumers purchase fresh agricultural products online because of the convenience of online shopping, and the price is lower than the physical store. 


\subsection{Supply structure optimization of fresh agricultural products platform}

Therefore, fresh agricultural products e-commerce should cooperate with agricultural production base and agricultural product supply base, further invest in the construction or joint production base to achieve the advantages of variety, quality and price, and realize the price that is lower than $15 \%$ of the agricultural market. E-commerce platform should also carry out regular market research, understand consumer demand, actively carry out high-quality fresh products network operation, constantly improve the management level of the platform, while tapping fresh products, improve the distribution efficiency of fresh agricultural products, strengthen storage construction, enhance consumer satisfaction, thereby eliminating online shopping worries of purchasing fresh products.

\section{References}

[1] Maarten C, Janssen W, Parakhonyak A. Price Matching Guarantees and Consumer Search[J]. International Journal of Industrial Organization, 2013,31(1):1-11.

[2] Cabra L. Dynamic Pricing in Customer Markets with Switching Costs. Review of Economic Dynamics 2016,20(4):43-62.

[3] Park J, Hill W.T, Bonds-Raacke J. Exploring the Relationship between Cognitive Effort Exertion and Regretin Online Vs. Offline Shopping [J]. Computers in Human Behavior, 2015,49(8): 444-450

[4] Nilashi M, Ibrahim O, Mirabi V The role of Security, Design and Content factors on customer trust in mobile commerce [J]. Journal of Retailing and Consumer Services. 2015, 26(9): 57-69

[5] Sweeney, Soutar. Consumer Perceived Value; The Development of a Multiple Item Scale [J]. Journal of Retailing, 2001, 77, (2);203-209.

[6] Posselt T, Gerstner E. Pre-sale vs. Post-sale Satisfaction Impact on Repurchases Intention and Overall Satisfaction [J]. Jounal of Interactive 2005, (4);35-47. 